DE DE GRUYTER OPEN
Journal of Intercultural Management

Vol. 6, No. 4, December 2014, pp. 147-157

DOI 10.2478/joim-2014-0041

\author{
Marcela Rebeca Contreras Loera* \\ Universidad de Occidente
}

Mónica Velarde Valdez*

Universidad de Occidente

\title{
Leadership in the fishing cooperative in Mexico
}

\begin{abstract}
The need to compete and grow encourages changes in organizations. In the fishing camps are created cooperatives, which know the reality of the environment and work with the aim of contributing to the development and progress of the fishermen and their communities. It is fundamental the role of its leaders, who have a responsibility to promote change in attitude and teamwork, to achieve personal and collective goals.

This paper presents preliminary results of a larger study which main objective was to identify the type of leadership that dominates in the management of the Sinaloa fishing cooperatives. The study was conducted under the qualitative paradigm; data collection was carried out with semi-structured interviews with managers and former directives of fishing cooperatives located in central Sinaloa, complemented by the application of a questionnaire covering their socioeconomic profile.

The main findings show that managers are fishermen, cooperative members, elected by the General Assembly as the highest organ of administration, with an average age from 35 to 45 years old, with basic school grades. They know about the productive activity of artisanal fisheries and occupy the job of president of the board in periods of 2-3 years without administrative preparation to run them. Regarding the predominant style of leadership, managers of fishing cooperatives say their efforts are focused on the development of organizational tasks such as setting goals and targets for each fishing season. In relation with the development of human relationships among members of the cooperative, indicate that their main concern is the quality of mutual relations and the level of involvement of partners, and with that in mind they implement strategies for the integration and participation in the opinions and decision making for the members. With the above it is concluded that managers of fishing cooperatives are young
\end{abstract}

*marcelac25@hotmail.com; mvelardemx@yahoo.com 
fishermen who run the organization with little training for the development of their job and they practice predominantly a style of democratic leadership, because they promote the participation of partners in both contribution of opinions as in decision making, strengthening the trust deposited in him at the time of his election as leader.

Key words: leadership, cooperative fisheries, management

\section{Introduction}

Today the world is undergoing a series of changes, influenced by various factors, both economic and social, that establish a strong transformation of organizations to enable them to adapt, survive and evolve; cooperative organizations are not exempt from this.

Cooperatives are required to have an administration capable of operating changes, improve resources, anticipate problems and make decisions that lead them to adapt quickly. The management of this organization is faced with the development of a dual role: one is to maintain the cooperative essence fulfilling the cooperative principles and internal rules and another role that requires having the preparation for the use of appropriate administrative tools.

The need for cooperation has motivated grouped humans from the earliest stages of civilization in order to improve their quality of life, starting with the exchange of goods obtained from hunting, fishing and gathering food.

Currently, the leadership role is of particular importance for achieving organizational competitiveness. Borboa, Rodriguez, Cereceres and Del Castillo (2006) note that in order to implement the required changes, it is important for the leaders to develop skills, personal characteristics and behaviors that allow them to establish the commitment of members to the competitiveness of the organization.

Whoever the leader is, he is the one who should consider leadership as a set of actions to help determine the goals of the group or to develop strategies to achieve them, without neglecting the quality improvement and group development.

Based on the above, arise questions like: What is the profile of the fishing cooperative management? What tasks performs the management of the fishing cooperative to fulfill its functions? What is the leadership style that dominates the management of the fishing cooperative?

The research aimed to analyze the characteristics of the management of the fishing cooperative and the predominant style of leadership. The study was conducted with the quantitative approach; data collection was conducted through surveys of 120 fishermen from fishing cooperatives in the center of the state of Sinaloa and who have served as president of the board, in various periods. 


\section{Theoretical references}

\section{The cooperative}

Cooperatives are organizations that do not belong to the traditional private sector or the public sector; they are given different names such as: the third sector, social economy, people's economy and comprise among other cooperatives, savings banks, mutual funds and non-profit associations, with growing importance, forming a so-called third sector, including public economics and private industry (Bastidas-Richer, 2001: p.7). On the other hand, are identified with two dimensions: 1) associative, which is reflected both in literature and in law when it is characterized as an open institution, nonprofit organization with a strong social responsibility and prioritizing its objectives addressing the needs of its partners and 2) business, as it explicitly includes the business nature of the organization (ACI, 2014).

Esteller (2002, p.8) notes that the cooperative has an immediate object that consists of activities undertaken to solve problems or meet the needs of their members or indirectly from the wider community where they develop their roles.

The most popular definition of cooperative, has been proposed by the Alianza de Cooperativas Internacional (International Cooperative Alliance; for its acronym in Spanish, ACI) which states: "A cooperative is an autonomous association of common persons united voluntarily to meet their common economic, social and cultural aspirations through a jointly and democratically controlled property" (ACI, 2014). In Mexico, according to the Ley General de Sociedades Cooperativas (General Law of Cooperative Societies; for its acronym in Spanish, LGSC), cooperative is a form of social organization composed of individuals based on common interests and on the principles of solidarity, self-help and mutual aid, in order to meet individual needs and collective, through the pursuit of economic activities of production, distribution and consumption of goods and services (LGSC, 2009, Article 2).

Unlike private companies, cooperative organizations are entities operating as non-profit, however require good management and administration to survive and fulfill its social mission (Braga, 2002, p.1).

As a result of the characteristics of the cooperative, management is delegated to a Board of Directors which in turn is subordinate to the maximum cooperative authority such as the General Assembly and appointing one member as a representative of the partners, performing the role of chairman of the board, who becomes the person responsible for leading the process for meeting the guidelines issued by the General Assembly.

In this respect adds Bertossi (2002, p.3) that the cooperative movement, represented by some successful cases, has strengthened its corporate character through the application of management techniques imported from the conventional company, changing behavior patterns to set a style steering close to the idiosyncratic features of the cooperative principles. 


\section{Definition of leadership}

Organizations are definitely the scenario of greater impact on the dynamics of transformation of modern civilization as it permeates all areas of human activity such as family, education, sports, science, art, politics, law, economics and society in general.

Kast and Rosenzweig (1988) cited by Chiavenato (1999) notes that organizations are not distant, impersonal phenomena; are inexorably intertwined with our daily lives. In this sense, the organization largely results to action groups (Donnelly, Gibson and Ivancevich, 1998).

One of the processes that generate greater impact in organizations today is the business management, which is based on the view that if the jobs and organizations are planned, organized and controlled properly, increases the overall development members of the organization as well as the productivity of the same. This implies that people with management skills are needed to learn how to use the skills of the staff, who are able to communicate, make decisions, resolve conflicts, to create a motivating and positive environment that promotes employee in achieving corporate goals that is, effective leadership (Donnelly, Gibson \& Ivancevich, 1996; Robbins, 1999).

The concept of leadership there are various interpretations; its meaning has been modified in accordance with changes in human development. By Fiedler (1961) cited by Kreitner and Kinicki (1997) considers leadership as a subjective fact that is the power structure of a group; while Robbins (1999) notes that it is the ability to influence a group so that the goals are achieved. The source of this influence may be formal, such as that provided by the possession of a general rank in an organization. For French and Bell (1996) leadership is a highly interactive and shared process in which members of all teams develop skills in the same process; involves setting a direction, vision and strategies to reach a goal, aligning people and motivating at the same time.

Leadership is also interpersonal influence exercised in a situation addressed through the process of human communication, to achieve one or several specific objectives. Leadership is seen as a phenomenon that occurs in social interaction; must be analyzed in terms of the relationships between people in a given social structure rather than by examining a series of individual characteristics (Chiavenato, 1999).

According to Siliceo, Casares and Gonzalez (1999), the leader at all levels and in all fields of human labor, is actually a builder of organizational culture, this being the set of values, traditions, beliefs, habits, norms, attitudes and behaviors that give identity, personality, meaning and purpose to an organization for achieving economic and social objectives.

Kast (1973) states that leadership is the process by which an individual consistently exerts more influence than others in carrying out the functions of the group. 
In addition, the author emphasizes that influence is not limited to a few occasions or actions, but must endure over time. This causes the leader's role to be permanent, meaning that attaches the ability to influence a particular group and for a temporary period.

According to Donnelly, Gibson and Ivancevich (1996) some authors have given the impression that leadership is synonymous with management; however, this is not correct; not only are the leaders in the hierarchy of management, but also in informal working groups.

The difference between leadership and management has been established as follows: leadership is a part of the management, but not all of it. Leadership is the ability to convince others to look forward to the achievement of defined objectives. It is the human factor that binds to a group and motivates towards objectives. Management activities as planning, organizing and making decisions are not effective until the leader stimulates the power of motivation in people and directs them towards the goals. Leadership is the way to move people and this is only part of the tasks of management (Ginebra, 1997).

\section{Theories of Leadership}

There is a big difference in taking a theoretical explanation of the leadership landscape within highlights four key approaches: 1) theories based on personal attributes, 2) behavioral theories, 3) the situational models and 4) attributional perspective. Despite the apparent differences in many aspects, these theories are considered to be complementary.

The approach of leadership has been taking relatively different courses that occur sometimes as cyclic waves reprising certain emphasis and diminish the value of others. Some approaches have evolved and added new elements to the premises raised by previous conceptions.

Older explanations on leadership were related to personal and invariant characteristics of individuals possessing that quality; in this approach are the trait theory, charismatic leadership and motivational theory. On the other hand, there are those who see leadership as a set of more specific behaviors exhibited by the leader and determine their style of interacting with subordinates and located to behavioral theories and transactional/transformational leadership. A less known approach evaluates leadership in terms of a social role (rational-bureaucratic theory).

A more recent approach developed the tenets of behavioral theory and subordinated its effect depending on the contextual conditions in which leadership is exercised; in this group are situational or contingencial theories. Finally, it has been recently addressed the issue of leadership as a perceptual phenomenon in which the perspective of attribution theory of leadership is located (Kreitner and Kinicki, 1997; Robbins, 1999; Hellriegel, Slocum and Woodman, 1999) 
For purposes of the study, situational leadership theory was used to explain a local situation regarding the management of the cooperative and its behavior. This approach includes a set of theories based on the idea that the leader's behavior would be affected by a number of factors in the context in which leadership is exercised and that it would determine its effectiveness (Kreitner and Kinicki, 1997); also, Adair (1990) found that leadership depends on the situation.

Within this group of theories, there are various approaches; one delves into the socio-emotional support that the leader provides to their followers as well as the situational requirements so that it can exert, ie, the support that the leader provides to a given situation (Rodriguez, 1988). A second theory in this sense, is developed by Fiedler (1961), cited by Robbins (1999); according to this, the group will perform adequately when suitable combination style of interaction between the leader and his subordinates occurs. This has two basic trends: task-oriented or relationshiporiented. The proper relationship between the leader's style and his subordinates depend on the characteristics of the task and the extent to which the situation gives control and influence to the leader, resulting in three basic considerations: a) degree of structuring of the task: this it can be high or low; b) amount of power available to the leader according to their position in the organization: this can be strong or weak; c) quality of interpersonal relationships between the leader and other members of the group: this can be good or poor.

Another proposal under this model is to Hersey and Blanchard, who argue that the style of leadership that the leader must exhibit to achieve optimal results, is solely based on the characteristics of followers, more specifically, the level of competition and disposition in collaborating with the leader's proposals. Despite what the leader does, effectiveness depends on the actions of his followers. Robbins (1999) notes that this is a dimension that has been overlooked in most theories of leadership.

\section{Leadership Styles}

There are several theories on behavior and leadership styles of managers in modern organizations, which are essential when studying the behavior of these references; one of the most used is the one proposed by Stoner (1996).

Stoner and others (1996, p.345) believe that leaders are characterized in three basic styles: a) The autocratic leader: orders and expects obedience, is dogmatic and positive and directed by the ability to withhold or give rewards and punishments. b) The democratic or participative leader: consulting with subordinates about the actions and decisions proposed and encourages participation thereof. c) The liberal: it uses very little power, if it does, as it gives subordinates a high degree of operational independence. These leaders rely heavily in their subordinates to set their own goals and means to achieve them and think their role is to support the operations of the followers. 


\section{Empirical Results}

In Mexico, the cooperative is governed by the Ley General de Sociedades Cooperativas; (General Law of Cooperative Societies); and in the case of fishing cooperatives by the Ley General de pesca y Ley general del equilibrio ecológico y la protección al ambiente (General Fisheries Law and General Law of Ecological Equilibrium and Environmental Protection), among others, bring the regulatory framework for its operations, because fishing is developed exploiting natural resources.

In Sinaloa fisheries and aquaculture have strong social and economic impact (GDP national fisheries 22.72). The fisheries sector is made up of coastal fishermen of medium height and tall, who are organized, mainly in fisheries cooperative societies' fish production. 38\% of employed personnel perform primary activities, of which $5 \%$ are engaged in fishing (INEGI, 2009). In the state of Sinaloa, commerce, agriculture, forestry, fishing and hunting, accounted for $20.8 \%$ and $13.2 \%$ of the state GDP figures 5.5 and 9.5 percentage points above the relative shares of these sectors at national level (INEGI, 2011).

Fishing has been characterized as a productive activity with extensive involvement of the social and private sectors. In this activity, a diversity of species, especially for its large volumes of production resources is obtained; such as tuna, shrimp, sardine, scale fish, crabs, dogfish shark.

In Sinaloa there are over 500 fishing cooperatives, of which 141 have been authorized for catching shrimp (species known for high quality and value in the national and international level). The study was conducted in 12 cooperatives that are active in bays located in rural communities (municipalities of Culiacan and Navolato, in the center of the state).

Regarding the management of the cooperative, it was found that $40 \%$ are between $50-60$ years old; while $33 \%$ are $40-50$ years old; $61 \%$ primary studied; $92 \%$ are married; 64\% having $1-3$ children, while 33\% have $4-6$ children; $63 \%$ indicates that his father was a partner and manager of the cooperative, of which $44 \%$ was Secretary, President $22 \%$ and $16 \%$ supervisory board chairman.

$23 \%$ of the executives surveyed indicate that they were chairmen of the board, while $32 \%$ supervisory board chairman, treasurer $23 \%$ and $16 \%$ vowel. $81 \%$ of managers indicated they received no training to perform their duties.

Regarding the behavior of the leader; $100 \%$ of the directors of the fishing cooperative partners are engaged in fishing; are elected by majority vote by the members of the organization, within the framework of the General Assembly (full board).

Under the bylaws of the cooperative, $100 \%$ of managers performs functions for the organization, direction and control of the capture and trade of the species caught; all indicate that the performance of its functions require the approval of the annual work plan presented at the meeting and note that one of the main respon- 
sibilities is to manage funding for the operation of organization and the establishment of cooperation agreements with buyers of production.

For the organization of activities, 95\% of managers indicated that the cooperative is divided into working groups, led by a leader who makes direct contact with the president of the cooperative;

$85 \%$ of the managers performed over a period of two years; $10 \%$ for three years and $5 \%$ over four years. $100 \%$ of managers indicated that they weren't trained to perform the job, while $80 \%$ said that members did their job without the need of being told so; $95 \%$ indicates that the shrimp catch is supervised by the president of the supervisory board

Regarding the degree of power management, $100 \%$ of managers indicated that they perform their function while the members desire so, because they can be removed from office at any time. $70 \%$ of managers suggest that the relationship with members is warm, while $30 \%$ said that there are conflicts between managers and members. The vision that workers generally have is of the boss ordering, command, decide, and say what to do, impose criteria, allocate work, monitor and supervise the work.

$100 \%$ of managers agree that the decision is made in consultation with the members, with the participation of all or the majority in the assembly meetings; likewise indicate that it is not easy to make effective decisions. On the other hand, $85 \%$ said that the information is insufficient to make quality decisions; $95 \%$ indicates that the performance of its functions are facing difficult to solve complex problems; 85\% believe that their decisions are accepted by the partners.

\section{Conclusions}

Leadership is an important aspect of management; for that is to influence people to strive willingly and enthusiastically to achieve group goals. In theory it should encourage people to develop not only a willingness to work but also the desire to do it with confidence; so that leaders help the group achieve its objectives through the maximum use of his abilities.

The fishing cooperative is characterized by being primarily led by the chairman of the board, who is appointed by the general meeting of members to fulfill that mission. This person performs work mainly characterized by being participatory, democratic and equitable.

The planning function, as a necessary tool to perform successfully and safety activities of the cooperative, it is carried out by managers in a deficient way because it they aren't prepare for the job, ignore the way that must be done; they don't establish clear goals and performance targets.

It tends to make informal plans and of little technical knowledge in a short-term trend. There is an absence of some form of social planning, which would guide the 
actions and results of the activities carried out to improve the social environment in which the organization operates.

The organizational structure, represented by the role of organization in the performance of managers is determined in its basic form by the general guidelines of the Ley General de Sociedades Cooperativas (General Law of Cooperative Societies), however each cooperative adapts the final form as needed. It's identified an existence of a simple, flexible and dynamic organizational structure in its performance, allowing it to adapt to the changing environment. In practice it has features to behave as a flat structure, where decisions are shared by all.

It is observed that the execution of tasks and functions are perform rather informal, since there are no manuals for the charges and procedures or person supervising the work of the group, since the tasks are shared among all members and between informality and trust it is ignore the proper monitoring, reviewing and troubleshooting tasks to implement corrective; monitoring is performed in the capture period (six months).

The managers of the studied cooperatives established policies to guide the operation of the cooperative, following the general guidelines of the meeting of members. The monitoring is done really shallow and just the simple fulfillment of tasks is found. There is a low level of formality, both in communication between members of the same, as in making various administrative decisions, but decisions that are medium to large importance are consulted with members of the same, thus achieving one participative management, with support from members.

The average education level of managers is mostly primary education, there are no plans for improvement and training, which means a low level of education, which influences the final results of the management of the organization. Also there are few incentives for workers recognition of achievements; perhaps this is due to lack of resources and lack of awareness of the need to assess the work of the members of the cooperative.

The managers, in their behavior as leaders, perform democratic and participatory leadership. Only when exceeded can be very liberal, but overall the trend is democratic. The atmosphere of brotherhood and camaraderie that exists within the cooperative, determines the presence of a communicative, open, flexible and democratic management, but mainly to maintain close contact with members of the cooperative.

The absence of an environment of punishment and tension, characteristic of organizations with autocratic leaders, in the cooperative generates greater participation in the various activities in which the views of members is required, which gives a sense of belonging to the members of the cooperative.

In general it is concluded that managers of the fishing cooperative has particular characteristics that differentiate organizations in the public and private sectors. The 
cooperative leader is a social leader by nature, democratic, participatory and eager to promote cooperatives as a lifestyle that seeks to improve society. However, little scientific and technical knowledge in administrative and managerial areas determine weaknesses in their development, which may affect the results of the current management.

\section{Bibliography}

Adair, J. (1990). Líderes, no jefes. Colombia: Legis Editores. http://www.normateca.gob. $\mathrm{mx} /$ Archivos/50_D_2173_09-09-2009.pdf

Alianza Cooperativa Internacional de las Américas (ICA, 2014). http://www.aciamericas. coop/Principios-y-Valores-Cooperativos-4456. Consultado el 15 de agosto de 2014.

Bastidas, O y Richer, M. (2001). Economía social, economía solidaria, economía popular: intento de definición. CAYAPA Revista Venezolana de Economía Social. Mayo 2001. Año $1 \mathrm{~N}^{\circ} 1$. Mérida. Venezuela.

Bertossi, Roberto. (2002). La Empresa Cooperativa. Ponencia presentada en el III Simposio Nacional de Economía Social. Asovac-Ciriec. Universidad Centroccidental Lisandro Alvarado. Barquisimeto. Noviembre 2002.

Borboa Quintero, María del Socorro, Marco Antonio Rodríguez Peñuelas, Lucia Cereceres Gutiérrez, Oswaldo Del Castillo Carranza (2006). Liderazgo para el desarrollo de la empresa sinaloense. Universidad Autónoma de Sinaloa.

Braga, Geraldo. (2002). Gerencia de Cooperativas: Comunicación, Educación Cooperativista y Participación. Ponencia presentada en el III Simposio Nacional de Economía Social. AsovacCiriec. Universidad Centroccidental Lisandro Alvarado. Barquisimeto. Noviembre 2002.

Chamorro Miranda, Diana Judith (2005). Factores determinantes del estilo de liderazgo del director-a. Memoria de doctorado. Madrid, 2005. http://biblioteca.ucm.es/tesis/edu/ ucm-t28589.pdf. Consultada el 10 de agosto de 2014.

Donnelly, 1.,Gibson, J. \& Ivancevich, 1.(1998). La Nueva Dirección de Empresas: De la Teoría a la Practica. Colombia: Editorial McGraw Hill.

Chiavenato, Idalberto. (1999) Introducción a la Teoría General de la Administración. Mc. Graw Hill. México.

Esteller, David. (1985). El Acto Cooperativo. Primera Edición, Vadell Hermanos Editores, Caracas.

French W. y Bell C. (1996). Desarrollo organizacional. México. Editorial Prentice Hall

Gibson, J., Ivancevich, J. \& Donnelly, J. (1996). Las organizaciones. Madrid: Editorial McGraw Hill

Ginebra, J. (1997). Líderes en acción. Colombia. Editorial Mc Graw Hill

Robbins S. (1999). Comportamiento organizacional. México. Editorial Prentice Hall

Gobierno del estado de Sinaloa (2014). Actividad económica, principales sectores, productos y servicios. http://www.sanjosedelrincon.gob.mx/work/templates/enciclo/ EMM25sinaloa/Economia.html 
Consultado el 15 de julio de 2014.

Kreitner y Kinicki (1997). Comportamiento de las organizaciones. Madrid. Mc Graw Hill

Instituto Nacional de Estadística y Geografía (2009). Sistemas de cuentas nacionales de México. Producto Interno Bruto por entidad federativa, 2005-2009. http://cuentame. inegi.org. $\mathrm{mx} / \mathrm{monografias} /$ informacion $/ \mathrm{sin} /$ economia/default aspx?tema $=$ me\&e $=25$. Consultado el 28 de julio de 2014.

Instituto Nacional de Estadística y Geografía (2011).

Producto Interno Bruto De Sinaloa 2005- 2009http://www.inegi.org.mx/inegi/contenidos/espanol/prensa/Boletines/Boletin/Comunicados/Especiales/2011/Abril/comunica25.pdf. Consultado el 10 de agosto de 2014.

Kast, Fremon E. y Jamex E. Rosenzweig (1973). Organizations and management: a systems approach. Mc Graw Hill, New York

Robbins, Stephen y Mary Coultier. (1996). Administración. Prentice Hall. México.

Kast, Fremont E. y Rosenzweig, James E. (1988). Administraci6n en las organizaciones. Un enfoque de sistemas y contingencias.

Rodríguez, M. (1988). Liderazgo: desarrollo de habilidades directivas. Serie: Capacitación integral. México. Manual Moderno

Siliceo, A., Casares, D. \& Gonzalez, 1. (1999). Liderazgo, Valores y Cultura Organizacional. Mexico: Editorial McGraw Hill.

Stoner, James (1996). Administración. Sexta Edición. Prentice Hall. Hispanoamericana S.A. México. 